$10-2019$

\title{
Temporal, spatial, and biological variation of nematode epidemiology in American eels
}

\author{
ZT Warshafsky \\ Virginia Institute of Marine Science \\ Troy D. Tuckey \\ Virginia Institute of Marine Science, tuckey@vims.edu \\ WK Vogelbein \\ Virginia Institute of Marine Science, wolf@vims.edu \\ RJ Latour \\ Virginia Institute of Marine Science, latour@vims.edu \\ AR Wargo \\ Virginia Institute of Marine Science, arwargo@vims.edu
}

Follow this and additional works at: https://scholarworks.wm.edu/vimsarticles

Part of the Aquaculture and Fisheries Commons, and the Marine Biology Commons

\section{Recommended Citation}

Warshafsky, ZT; Tuckey, Troy D.; Vogelbein, WK; Latour, RJ; and Wargo, AR, "Temporal, spatial, and biological variation of nematode epidemiology in American eels" (2019). VIMS Articles. 1780.

https://scholarworks.wm.edu/vimsarticles/1780 


\section{Canadian Journal of Fisheries and Aquatic Sciences}

\section{TEMPORAL, SPATIAL, AND BIOLOGICAL VARIATION OF NEMATODE EPIDEMIOLOGY IN AMERICAN EELS}

\begin{tabular}{|c|c|}
\hline Journal: & Canadian Journal of Fisheries and Aquatic Sciences \\
\hline Manuscript ID & cjfas-2018-0136.R2 \\
\hline Manuscript Type: & Article \\
\hline $\begin{array}{r}\text { Date Submitted by the } \\
\text { Author: }\end{array}$ & 17-Nov-2018 \\
\hline Complete List of Authors: & $\begin{array}{l}\text { Warshafsky, Zoemma; Virginia Institute of Marine Science, Aquatic } \\
\text { Health Sciences } \\
\text { Tuckey, Troy; Virginia Institute of Marine Science } \\
\text { Vogelbein, Wolfgang; Virginia Institute of Marine Science } \\
\text { Latour, Robert; Virginia Institute of Marine Science, Fisheries Science } \\
\text { Wargo, Andrew; Virginia Institute of Marine Science, Aquatic Health } \\
\text { Sciences }\end{array}$ \\
\hline Keyword: & $\begin{array}{l}\text { EPIDEMIOLOGY < General, PARASITES < Organisms, ESTUARIES < } \\
\text { Environment/Habitat, CATADROMOUS SPECIES < Organisms }\end{array}$ \\
\hline $\begin{array}{r}\text { Is the invited manuscript for } \\
\text { consideration in a Special } \\
\text { Issue? : }\end{array}$ & Not applicable (regular submission) \\
\hline
\end{tabular}

\section{SCHOLARONE ${ }^{\text {IM }}$ \\ Manuscripts}




\title{
TEMPORAL, SPATIAL, AND BIOLOGICAL VARIATION OF NEMATODE EPIDEMIOLOGY IN AMERICAN EELS
}

\author{
Zoemma T. Warshafsky, Troy D. Tuckey, Wolfgang K. Vogelbein, Robert J. Latour, \\ Andrew R. Wargo. Virginia Institute of Marine Science, College of William \& Mary, P.O. Box \\ 1346, Gloucester Point, VA, 23062, USA.
}

Corresponding author: Z.T. Warshafsky (email: zoemmaw@gmail.com)

\section{ABSTRACT}

American eels (Anguilla rostrata) are infected by the non-native parasitic nematode Anguillicoloides crassus, which can cause severe swimbladder damage. We investigated epidemiology of A. crassus to better understand its population-level effects on American eels. Nematode prevalence, abundance, and intensity, and swimbladder damage were quantified in glass eels, elvers, and yellow eels from the lower Chesapeake Bay and related to season of capture, river system, and total length. Age-variant force-of-infection and disease-associated mortality were estimated using a three-state irreversible disease model, which assumes recovery is not possible. Results showed glass eels have very low infection prevalence and severity compared to elvers and yellow eels. Nematode abundance varied by season, river, and eel length, whereas swimbladder damage varied by season and eel length. Nematode abundance and swimbladder damage were weakly positively correlated. Force-of-infection, based on swimbladder damage, peaked at age 2 and disease positive eels had an estimated lower annual survival probability of 0.76 compared to disease negative eels. Full understanding of American eel population dynamics will require broader knowledge of cryptic disease-associated mortality throughout North America. 


\section{INTRODUCTION}

4

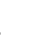

The American eel (Anguilla rostrata) is an economically and ecologically important, yet relatively data-poor, species distributed along the Atlantic coast of North America and throughout the Gulf of Mexico (ASMFC 2012). The American eel population has been declining for the past several decades and is currently considered depleted and at a historically low level of abundance according to the most recent stock assessment update by the Atlantic States Marine Fisheries Commission (ASMFC 2017). Several hypotheses have been proposed to explain the species' decline such as overfishing, pollution, changing climate, altered habitats and food webs, parasites, and emergent disease (Castonguay et al. 1994; Haro et al. 2000). One such proposed hypothesis is the impact of the introduced parasitic nematode, Anguillicoloides crassus, which can cause severe damage to the swimbladders of American eels.

2
Infection by Anguillicoloides crassus is endemic in the Japanese eel (Anguilla japonica) in Asia, but significant pathology or notable negative population level impacts have not been observed (Sokolowski and Dove 2006). In contrast, the emergence, rapid spread, high prevalence, and pathogenicity of $A$. crassus have been linked to declines in wild European eel (Anguilla anguilla) populations and in European eel aquaculture facilities in Asia (Barse et al. 2001; Ooi et al. 1996). Within the American eel population, the parasite was first discovered in 1995 in a Texas aquaculture facility and was first observed in wild animals in South Carolina that same year (Fries et al. 1996). Since its discovery, the distribution of A. crassus has expanded rapidly and now occurs in eels in the Gulf of Mexico northward to Nova Scotia (Rockwell et al. 2009). In the Chesapeake Bay, where approximately $60 \%$ of the annual U.S. catch of eels is landed (ASMFC 2017), A. crassus was first detected in 1997 (Barse and Secor 1999) and 
63 currently can be found in all major tributaries with prevalences as high as $80 \%$ (Barse et al.

64 2001; Fenske et al. 2010).

Eels become infected by consuming intermediate hosts such as copepods and ostrocods

66 or by ingesting paratenic hosts (i.e., intermediate hosts in which parasite development does not

67 occur) such as fishes, amphibians, snails, or insect larvae (Thomas and Ollevier 1992; Moravec

68 1996; Moravec and Skorikova 1998). Once inside the eel, the parasite moves from the alimentary

69 tract through the body cavity, eventually taking up residence in the swimbladder where it

70 matures, sexually reproduces, and then dies and decays or is forced out through the pneumatic

71 duct (Haenen et al. 1989; De Charleroy et al. 1990). Damage to the eel occurs as a result of

72 larval nematode migration through the swimbladder wall, feeding on blood by adults, and

73 inflammation and degradation of dead adults within the swimbladder lumen (Sokolowski and

74 Dove 2006). Damage clinically manifests as increased opacity, thickening, and pigmentation of

75 the swimbladder wall (Lefevbre et al. 2011). Tissue damage by $A$. crassus can be so severe that it

76 results in complete degradation and loss of swimbladder function (Molnar et al. 1995; Wurtz et

77 al. 1996; Kobyashi et al. 1990). However, the adverse health impacts of this infection and its

78 impacts on eel population dynamics are not well understood, in part due to a complex

79 relationship between parasite abundance and degree of swimbladder damage, suggesting that

80 severe damage may prevent subsequent infections (Lefevbre et al. 2013).

Previous studies addressing the impacts of $A$. crassus have mainly focused on infection

82 prevalence and mean intensity (Fenske et al. 2010; Aieta and Oliveria 2009; Hein et al. 2014),

83 but these metrics may provide an inaccurate or incomplete characterization of the multifaceted

84 epidemiology. Potential discrepancies in the relationship between parasite abundance and

85 swimbladder damage may be caused by intermediate and paratentic host dynamics, A. crassus 
dying within the swimbladder and decaying or being cleared, and the possibility that a highly

87 damaged swimbladder may not serve as a suitable habitat for $A$. crassus (De Charleroy et al. 1990; van Banning and Haenen 1990). Additionally, previous analyses have focused mainly on yellow eels and have not included younger life stages, despite potential susceptibility of those stages to infection (Hein et al. 2015; De Charelory et al. 1990). Finally, it is not known if $A$. crassus causes infection-associated mortality (Lefebvre et al. 2013), which greatly limits understanding of the population level impacts of this parasite in American eels.

The objectives of our study were to (1) quantify prevalence, abundance, and intensity of Anguillicoloides crassus infections in glass, elver, and yellow stage American eels in the Chesapeake Bay; (2) clarify the relationships between parasite abundance and swimbladder damage and the impacts of capture location, eel size, and season on the infection; and (3) model A. crassus force of infection in Chesapeake Bay, including exploration of spatiotemporal covariate effects, and evaluate disease-associated morality. Collectively, our results support ongoing American eel management efforts by addressing key questions related to patterns in disease prevalence and population impacts of $A$. crassus.

\section{METHODS}

\section{Field collections}

Glass and elver stage American eels were collected from six sites within the lower Chesapeake Bay from March through June 2015 using Irish eel ramps (Figure 1). Traps were placed in areas of freshwater runoff and a dam that impeded the eels' upstream movements. The six sites were on the James River (Wareham's Pond), York River (Bracken's Pond and Wormley 
109 Pond), Rappahannock River (Kamp's Millpond), and Potomac River (Clark's Millpond and 110 Gardy's Millpond). Sampling was conducted according to protocols established by the ASMFC 111 for monitoring young-of-year glass eels (ASMFC 2012). Traps were checked a minimum of two 112 days per week, with increasing frequency depending on the strength of glass eel ingress. On the 113 first sampling day of each week, a maximum of 30 glass eels and 20 elvers were collected if 114 possible, followed by up to 10 glass eels and 5 elvers each subsequent sampling day depending 115 on their availability. This sampling technique was designed to optimize collecting enough eels to 116 detect the nematode at low prevalence and reducing potential sampling biases such as 117 autocorrelation within a catch (i.e., pseudoreplication associated with cluster sampling).

118 Differentiation between glass eels and elvers was based on pigmentation stage (Haro and Kruger 119 1988), with fully pigmented eels considered elvers, and the incompletely pigmented eels 120 considered glass eels. Yellow stage American eels were collected from 2013 to 2015 by the VIMS Seine 122 Survey and Juvenile Fish Trawl Survey (Tuckey and Fabrizio 2013) and opportunistically from 123 the Virginia Department of Game and Inland Fisheries Electrofishing Survey. The Trawl and 124 Seine Surveys sampled eels in primarily brackish and tidal fresh water, whereas the 125 Electrofishing Survey sampled eels in mainly freshwater locations. Yellow eels were collected 126 within the James, York, and Rappahannock River watersheds from all three surveys, whereas 127 yellow eels in the Potomac River watershed were collected exclusively by electrofishing.

\section{Laboratory processing}

Weights (nearest $0.001 \mathrm{~g}$ ) and lengths (nearest $0.01 \mathrm{~mm}$ total length) were obtained from

131 glass eels and elvers that were euthanized using clove oil, measured, and then frozen $\left(-18^{\circ} \mathrm{C}\right)$ for 
132 storage. Yellow eels were euthanized using an ice slurry, frozen immediately, and weighed

133 (nearest $0.1 \mathrm{~g}$ ) and measured (nearest $1 \mathrm{~mm}$ ) following thawing just prior to dissection. For all

134 eels, the swimbladder was removed after thawing and opened to enumerate adult A. crassus.

135 Counts of larval $A$. crassus in the swimbladder wall were quantified for glass eels under a

136 dissecting microscope, after placing the swimbladder between two glass slides. Only adult $A$.

137 crassus parasites were recorded for elvers and yellow eels. Swimbladder condition was

138 quantified using the Swimbladder Degenerative Index (SDI; Lefevbre et al. 2002). This index

139 quantifies three swimbladder attributes - bladder wall opacity, thickness, and pigmentation and

140 exudate (e.g. dead worms, erythrocytes, decaying swimbladder tissue, eggs, and L2 stage of $A$.

141 crassus; Lefebvre et al. 2002) with each of these ranked from 0 (healthy, normal condition) to 2

142 (severe condition). The three attribute scores were added together to generate a total SDI ranging

143 from 0 to 6. Due to the difficulty of detecting eggs and L2 stage $A$. crassus in swimbladders,

144 these two types of exudate were not used to determine the presence of exudate in elvers and 145 yellow eels, but were used in glass eel analyses.

146 Sagittal otoliths were extracted from elvers and yellow eels and processed for age

147 determination (Michaud et al. 1988; Cieri and McCleave 2000; Morrison and Secor 2003).

148 Otoliths were mounted on a glass slide with CrystalBond ${ }^{\mathrm{TM}}$ and sanded down in the frontal plane 149 until the core was visible. The otolith was then flipped and the opposite end was sanded down 150 until the otolith was transparent and annuli were clearly visible. Annuli were quantified using a 151 compound microscope. Each otolith was read independently by two readers and those specimens 152 with annulus counts that differed were read again. Final age assignments were based on 153 consensus between readers. Because eels have been in the Atlantic Ocean for about one year 154 prior to metamorphosing into glass eels and the first annulus may not be laid down until after a 
155 full year in coastal waters (ASMFC 2017), one year was added to all ages. Protocols for 156 sampling and euthanizing eels were approved by the College of William \& Mary's Institutional 157 Animal Care and Use Committee.

158

Statistical analyses

Infection prevalence (proportion of eels infected with nematodes), mean abundance (average number of nematodes across all eels surveyed, infected and uninfected), and mean

162 infection intensity (average number of nematodes per infected eel) were calculated from all eel

163 stages and river systems using adult $A$. crassus counts (Bush et al. 1997). Glass eel analysis

164 included both the adult and larval stages of the parasite. For all following analyses, a plausible 165 set of candidate model parameterizations was defined based on hypotheses regarding potential 166 effects of covariates (i.e., the covariates included in models have been shown to be important in 167 other studies or represent plausible hypotheses unique to this study). Final models were selected 168 using a combination of goodness of fit measures and Akaike's Information Criterion value (AIC;

169 Burnham and Anderson 2002).

170

171 Parasite abundance

172 For glass eels, the probability of infection by $A$. crassus larval and adult stages combined 173 in relation to glass eel total length (TL) was investigated using a binomial generalized linear 174 model with a logit link function. The inflection point, or the TL at which the probability of being 175 infected is 0.5 , of the binomial model was calculated and its standard error was estimated using 176 the delta-method (Seber 1982). Glass eels were excluded from subsequent analyses due to low 177 prevalence and infection intensity. 
For elvers and yellow eels, preliminary analyses comparing AIC values of the fully

179

180

181

182

183

184

185

186

187

188

189

190

191

192

193

194

195

196

197

198

199 statured model (all covariates in both count and zero model components) to the fully saturated count model that includes only the intercept in the zero component indicated that parasite count data were zero-inflated (i.e., an excess frequency of zeros in the dataset; $\triangle \mathrm{AIC}=74.6$ ).

Therefore zero-inflated negative binomial models were used to explore the effects of covariates on parasite abundance and the probability of a false zero, or the absence of parasites due to design, survey, or observation error (Zuur et al. 2012). The covariates included river system (James, York, Rappahannock, Potomac), season (created by assigning the date of capture into the four seasons based on the solstices and equinoxes of that year), SDI, and TL. Multiple model parameterizations were considered that reflected different combinations of covariates for the count and false zero model components. The dispersion parameter $\left(d=\sum \frac{\text { residual }^{2}}{\text { df(residual })}\right)$, which indicates overdispersion when $d>1$, and the Pearson residual versus fitted value plots were used to evaluate goodness of fit of the models. Partial predictions from the most empirically supported model were generated using marginal means (Searle et al. 1980).

$S D I$

The swim bladder degenerative index (SDI) is an ordered categorical response variable, requiring a specific regression framework to capture the sequential nature of the data. The ordinal logistic regression (or cumulative logit model) meets this requirement by modelling the probability of an eel having a certain level of swimbladder damage (i.e., SDI score) or lower against all higher levels (Agresti 2010; Hedeker 2003; McCullagh 1980) such that:

$$
\operatorname{logit}\left(P\left(Y_{i j} \leq c\right)\right)=\theta_{c}-\left(\boldsymbol{x}_{i j}^{t} \boldsymbol{\beta}+\boldsymbol{u}_{i j}^{t} \boldsymbol{\alpha}_{c}+v_{i}\right)
$$


200 The cumulative $\operatorname{logit}\left(P\left(Y_{i j} \leq c\right)\right)$ represents the cumulative probability of the $j^{\text {th }}$ eel from the $i^{\text {th }}$ 201 catch having a $c^{\text {th }}$ level of swimbladder damage. The parameter $\theta_{c}$ represents strictly increasing 202 model thresholds $(1, \ldots, C-1)$. The covariate vector $\boldsymbol{x}_{i j}$, which includes the intercept, follows 203 the proportional odds assumption such that there is only one vector of regression parameters $\boldsymbol{\beta}$ 204 for each covariate. Covariate vector $\boldsymbol{u}_{i j}$ follows partial proportional odds such that there is a 205 different vector of regression parameters $\boldsymbol{\alpha}_{c}$ for every level of $c$ for each covariate (Agresti 2010; 206 Hedeker 2003; McCullagh 1980). The parameter $v_{i}$ is the random effect for catch $i$ distributed $207 N\left(0, \sigma_{v}^{2}\right)$. Odds ratios $(Y \geq j)$ are obtained through exp $(\boldsymbol{\beta})$, and indicate the odds ratio of a 208 swimbladder having a damage level $c$ or higher for a given level of a covariate (Agresti 2010; 209 Hedeker 2003; McCullagh 1980).

The proportional odds assumption (or parallel regression assumption), states that the odds ratios of the different levels of a covariate are equal across all thresholds of swimbladder damage 212 levels, necessitating only one $\boldsymbol{\beta}$ coefficient. For example, for a given covariate (e.g. season), the 213 ratio of the odds of having a certain swimbladder damage level in one season (e.g. spring) to the 214 odds of having the same swimbladder condition in another season (e.g. winter) are equal across 215 all thresholds of swimbladder damage levels. This does not mean that the odds of swimbladder 216 damage within one level of a covariate are equal, but instead that the odds ratios of two levels of 217 a covariate are equal (i.e. proportional odds). This assumption can be relaxed by utilizing partial 218 proportional odds, which allows coefficient $\boldsymbol{\alpha}_{c}$ to vary with thresholds of SDI scores and 219 therefore not have equal odds ratios between levels of a covariate. This approach was used to explore the effects of covariates river system, TL, season, 221 parasite abundance, and catch ID (random effect) on the odds of having attained greater than or 222 equal to the $c^{\text {th }}$ level of swimbladder damage. Due to low sample size of higher parasite 
223 intensities, a plus group was defined such that intensities ranged from zero to $10+$. To aid

224 convergence and model interpretation, SDI scores were condensed into three ordered levels (low:

225 0-1, moderate: $2-3$, severe: $4-6$, such that $c=0,1,2)$. The proportional odds assumption was

226 evaluated by fitting multiple models with and without covariates as partial proportional odds, and

227 AIC was used for model selection. Overall goodness of fit was evaluated using the condition

228 number of the Hessian, for which values larger than $10^{6}$ indicate that the model may be ill

229 defined (Christensen 2015). Partial predictions from the model with the most empirical support

230 were generated using marginal means (Searle et al. 1980).

231

232 Epidemiology

233 To estimate the probability that an uninfected eel becomes infected, termed force-of-

234 infection (FOI), and evaluate the potential presence of infection-associated mortality, we applied

235 a three-state irreversible disease model (see Heisey et al. 2006 for full details). The model is

236 designed to provide estimates of key epidemiological parameters from cross-sectional (i.e. data

237 representing multiples ages or cohorts) from binary prevalence-at-age data (i.e. either disease

238 positive or disease negative at a given age). The model assumes no vertical transmission (i.e.,

239 transmission from mother to offspring) or recovery to a state of full health. Force-of-infection

240 can be either age-invariant or age-dependent, and the Weibull, Pareto, Gompertz, and log-logistic

241 hazard functions were evaluated to identify the appropriate functional shape of the FOI curve

242 (Heisey et al. 2006). The model also allows for estimation of an additive disease-associated

243 mortality parameter that represents the additional mortality rate experienced by disease-positive

244 individuals relative to the background mortality rate of disease-negative individuals. 

infection were investigated using log-linear models such that:

$$
\lambda(t)=\lambda_{0}(t) e^{X \beta}
$$

248 The age-dependent FOI, denoted $\lambda(t)$, is modeled as the baseline FOI, $\lambda_{0}$ adjusted by the effects

249 of covariates included in the design matrix $X$ and the associated vector of parameters $\beta$ (Heisey et 250 al. 2006). The covariate month was redefined to represent two-month time periods (six levels) 251 starting with January/February. Due to low sample size of older eels, a plus group was defined so 252 that ages ranged from 1 to $12+$. Disease-positive eels were those that had a swimbladder with an 253 SDI score $\geq 3$. Because $A$. crassus can die within the swimbladder and degrade or be expelled 254 through the pneumatic duct, prevalence does not meet the no-recovery assumption of the force of 255 infection model (i.e., damage to the swimbladder has occurred, but an absence of parasites does 256 not accurately capture the damage). As such, force-of-infection modelling was not conducted on 257 infection prevalence data.

258 All statistical analyses were performed using the R software package (R Core Team 259 2014). The 'pscl' package was used for fitting zero-inflated GLMs (Zeileis et al. 2008) and the 260 'ordinal' package (Christensen 2015) was used for fitting ordinal logistic regression models. 261 Results are presented as the mean or estimate \pm standard error.

262

264 RESULTS

265 Anguillicoloides crassus infection and disease in glass eels

266 A total of 1480 glass eels were collected from all six sites ranging in total length from 47.3 to $267 \quad 77.5 \mathrm{~mm}$ (mean: $57.6 \mathrm{~mm} \pm 0.103$ ). Adult and larval nematode counts in glass eels were 
268 combined and yielded an overall infection prevalence of $3.2 \%$, mean nematode abundance per 269 eel of $0.047 \pm 0.009$ (range: $0-10$ ), and mean infection intensity of $1.46 \pm 0.195$. Only glass eels 270 collected in the Potomac and Rappahannock rivers were infected (Table 1). Glass eels had higher 271 infection levels of the larval stage of A. crassus (prevalence: $2.5 \%$, mean abundance: $0.039 \pm$ 2720.009 , mean intensity: $1.57 \pm 0.25$, range: 0 -10) compared to the adult stage (prevalence: $0.8 \%$, 273 mean abundance: $0.008 \pm 0.002$, mean intensity: $1 \pm 0$, range: $0-1)$. The probability of infection 274 by larval and adult nematodes combined increased with the length of glass eels (Figure 2). The 275 TL with a 0.5 probability of being infected was $78.3 \pm 2.8 \mathrm{~mm}$. Furthermore, only the more 276 advanced pigment stages of glass eels were found to be infected with larval and adult $A$. crassus, 277 and only the highest pigment stages of 5 and 6 showed any swimbladder damage. Overall, 278 minimal swimbladder damage was found with only seven glass eels having scores greater than 0 279 (mean SDI: $1.14 \pm 0.143$ ).

\section{A. crassus infection and disease in elver and yellow eels}

Across all six sampling sites, a total of 814 elvers were collected and total length ranged from 49.0 to $238.0 \mathrm{~mm}$ (mean: $113.8 \mathrm{~mm} \pm 1.02$ ). Adult nematode prevalence was $59.2 \%$, mean abundance per eel was $1.51 \pm 0.061$, mean intensity per infected eel was $2.44 \pm 0.072$, and average SDI was $1.62 \pm 0.055$. When summarized by river system, James River elvers showed the highest prevalence $(66.7 \%)$, average abundance $(1.83 \pm 0.13)$, mean intensity $(2.73 \pm 0.13)$,

287 and average SDI $(1.82 \pm 0.11)$; however the difference in mean infection and disease levels between sites was small (Table 1). There was substantial variation between individual elvers 6) was observed. 
A total of 973 yellow eels were collected across all four river systems and all three surveys. Total length of these individuals ranged from 60.0 to $700.0 \mathrm{~mm}$ (mean: $285.9 \mathrm{~mm} \pm$ 3.71). Adult nematode prevalence was $46.2 \%$, mean abundance per eel was $1.35 \pm 0.079$, mean intensity per infected eel was $2.92 \pm 0.136$, and average SDI was $2.44 \pm 0.055$. Yellow eels from the Potomac River showed the highest prevalence (55.2\%), whereas those from the Rappahannock River exhibited the highest mean abundance $(1.53 \pm 0.13)$ and mean intensity

$297(3.09 \pm 0.22)$. Those from the James River displayed the highest average SDI $(2.3 \pm 0.08)$, 298 although mean differences between sites was again small (Table 1). As with elvers, there was 299 substantial variation among individuals in infection intensity and disease, such that infection intensity in yellow eels ranged from 0 to 28 nematodes and the full range of SDI scores (0-6) was 301 observed.

\section{Parasite abundance}

The full zero-inflated negative binomial with river system, season, TL, and SDI as covariates for both the zero-inflated and count components of the model received the most empirical support (i.e., lowest AIC score; Table S1), had a dispersion parameter value close to one (1.16), and the Pearson residual versus fitted value plot showed this model fit the data well.

308 This model was closely followed $(\triangle \mathrm{AIC}<2$, dispersion $=1.15)$ by a model without SDI in the 309 zero-inflated component. Due to the importance of SDI in the analysis and the lower AIC, the 310 full model was selected for inference. When comparing parasite abundance (Table 2) using the count model, the estimated 312 effect for the Potomac River indicated lower mean parasite abundance relative to the James 313 River $(-0.452 \pm 0.112)$, whereas the estimated effects of the Rappahannock and York Rivers also 
314 indicated lower mean parasite, though much smaller in magnitude $(-0.135 \pm 0.103$ and $-0.015 \pm$

3150.103 respectively, Figure 3). Regarding season, the estimated effects of spring and summer

316 indicated similar higher mean parasite abundances relative to fall $(0.294 \pm 0.130$ and $0.224 \pm$

3170.138 respectively), whereas winter showed a lower mean parasite abundance $(-0.149 \pm 0.316$,

318 Figure 3). The estimated effect of TL indicated a positive relationship to parasite abundance

$319\left(1.37 \times 10^{-3} \pm 4.42 \times 10^{-4}\right)$. However, due to zero-inflation, the relationship between TL and 320 predicted parasite count was dome-shaped; the exception being both the Potomac River across

321 all seasons and winter across all river systems where the relationship was continuously

322 increasing due to very low zero-inflation (Figure 3). For SDI, parasite abundance was higher for

323 all scores compared to the baseline (SDI 1: $0.279 \pm 0.124$, SDI 2: $0.512 \pm 0.116$, SDI 3: $0.295 \pm$

$324 \quad 0.131$, SDI 4: $0.502 \pm 0.156$, SDI 5: $0.387 \pm 0.194$, SDI 6: $0.500 \pm 0.238$, Figure 3).

325

\section{Swimbladder condition}

The ordinal logistic regression model with the most empirical support included TL as a

328 proportional odds covariate, season and parasite abundance as partial proportional odds

329 covariates, and catch ID as a random effect (Tables 3 and S2). Inclusion of the random factor

330 resulted in a significant drop in AIC $(\triangle \mathrm{AIC}=128.7)$, despite only a few eel catches appearing to

331 drive the effect (Figure S1), and therefore it was selected for inference. The condition number of

332 the Hessian for the selected model was $1.3 \times 10^{7}$, which is slightly above the recommended value

333 of $10^{6}$. Dropping season from the model resulted in a lower Hessian value of $6.5 \times 10^{6}$, but raised

334 the $\mathrm{AIC}(\triangle \mathrm{AIC}=8)$. The results for the other covariates were unchanged between the two

335 models, so season was ultimately included in the final model. 
This model indicated that increasing TL was associated with an increase in the odds of having a more damaged swimbladder $(0.004 \pm 0.001$, Figure 4$)$. As such, the longer an eel, the more likely it has a more damaged swimbladder. Also, the overall trend between parasite abundance and swimbladder damage was a positive relationship. The parasite abundance coefficients were negative (low versus moderate/severe condition: $-0.2 \pm 0.04$ and low/moderate versus severe condition: $-0.12 \pm 0.04$ ) yet, when added to the positive model intercepts (low versus moderate/severe condition: $0.39 \pm 0.29$ and low/moderate versus severe condition: $3.15 \pm$ 0.31), the sum of the log odds was still a positive value. Therefore, increasing parasite abundance resulted in an increased probability of swimbladder damage, but this increased probability was reduced by the underlying negative relationship (Figure 4). The effect of season was minimal,

346 with only the estimated effect of having a severely damaged swimbladder in the summer relative

347 to fall indicating a decreased odds $(-0.8 \pm 0.29$, Figure 4$) ..$ The odds among the three

348 swimbladder conditions were not found to differ between the other seasons and fall (i.e.

349 estimates \pm standard error overlapped zero, Figure 4). Overall, eels had a higher predicted 350 probability of having a moderately damaged swimbladder $(0.566 \pm 0.063)$ compared to a low 351 $(0.310 \pm 0.042)$ or severely $(0.124 \pm 0.051)$ damaged swimbladder.

\section{Force of infection and disease associated mortality}

Sixty-four elvers and 661 yellow eels were included in the force of infection analysis, 355 ranging in age from 1 to 16 years (age range of 1 to $12+$ used in analysis due to small sample size of older individuals). Observed prevalence of swimbladder damage increased steeply from

357 age 1 to 2 and then slowed to a slight increase with age, whereas observed prevalence of $A$. 
crassus infection was highest in the younger and older eels but lower in the middle ages (Figure $5)$.

Age-dependent force-of-infection models received more support than age-invariant models when fitted to prevalence of swimbladder damage data (Table 4). The model with the most empirical support was the log-logistic with month pairs and the mortality term, though several other models were within three AIC units (Table 4). Across hazard models parameterized with the same set of covariates, inclusion of the mortality term lowered the AIC for all except for the Gompertz models (Table 4). Additionally, the combination of month pairs and the morality term resulted in the lowest AIC value within each set of hazard models, excluding the Gompertz hazard models (Table 4). The unit hazard ratios (i.e., proportional difference in force of infection) for month pairs relative to the baseline of November/December were January/February: 0.026, March/April: -0.793, May/June: -0.294, July/August: -0.430, and September/October: -0.486 . Force of infection peaked at age 2 and then decreased with subsequent ages (Figure 6). The disease-associated mortality term was estimated as 0.277 (95\% CI: $0.0845-0.507)$ and the annual survival ratio of a diseased eel relative to a non-diseased eel is $e^{-(-0.277)}$ (Heisey et al. 2006) or 0.76 (95\% CI: 0.602-0.919).

Other cutoffs of swimbladder damage level considered indicative of infection (i.e. SDI $\geq$ $1,2,4,5$, or 6 ) were explored. Similar results were found in these analyses such that the mortality term was included in either the model with the most empirical support or in models within 2 AIC units of the selected model. Additionally, month was usually (4 out of 6 cases) a covariate in the model with the most empirical support. Likewise, force of infection peaked at age 2 in almost all cases (Figure S3). 


\section{DISCUSSION}

Our study indicates that $A$. crassus infection and resultant swimbladder pathology vary across host developmental stages and are influenced by environmental factors experienced by American eels, which may ultimately result in disease-associated mortality. Infection prevalences of over $50 \%$ were found in elvers and yellow eels, compared to only $2.5 \%$ in glass eels. In general, similar patterns were observed in several previous studies of A. crassus in the Chesapeake Bay region (Barse and Secor 1999; Barse et al. 2001; Fenske et al. 2010). Low infection prevalence in glass eels, also observed by Hein et al. (2015) in South Carolina, are potentially due to less time in the estuary and therefore less exposure to A. crassus, given that eels first come in contact with the parasite in coastal waters (Van Banning and Haenen 1990). This conclusion is also supported by finding mostly larval stage nematodes in glass eels in our study, although Hein et al. (2015) found only adult nematodes. This difference could be due to sampling location — glass eels in our study were caught in more brackish downstream sites (with the exception of our Potomac sites) where they were most likely first exposed to $A$. crassus, and eels collected in the South Carolina study were caught further up-river allowing more time for

397 infection by larval A. crassus and develop into adults (Hein et al. 2015). Our analyses also 398 indicated that season, size, and age differences in susceptibility, transmission, and mortality could be drivers of observed in variation of infection and disease for elver and yellow eels. 
404 driven by eel behavior and the abundance of $A$. crassus in the environment. For example, eels are

405 believed to be dormant in the cooler winter months (Kennedy and Fitch 1990), but as the water

406 warms in spring, they become active and commence feeding, which likely increases their

407 exposure to $A$. crassus through consumption of intermediate and paratenic hosts. Additionally, at

408 lower temperatures, the reproductive cycle of the parasite slows (Kim et al. 1989; Nagasawa et

409 al. 1994; Knopf et al. 1998), which may reduce parasite abundance and swimbladder damage in

410 the colder months. Seasonal differences could therefore indicate the existence of a lag between

411 acquiring parasites in the spring and accumulating damage from these parasites in the summer,

412 although future research is needed to explore the timing of infection and how this relates to

413 swimbladder damage.

$414 \quad$ For both parasite abundance and swimbladder damage, TL had a positive relationship. By

415 including zero-inflation in our analysis of parasite abundance, we were able to reveal that the

416 highest parasite abundances occur around $300 \mathrm{~mm}$ TL relatively consistently across seasons,

417 river systems, and swimbladder conditions. The mechanisms behind this relationship are

418 unknown, but it is likely that as eels get larger, they consume more prey and are more exposed to

419 A. crassus. Larger eels also have bigger swimbladders, which may provide more habitat for the

420 parasite. It is then possible that after eels reach a certain size, various aspects of parasite and

421 swimbladder damage accumulation drive prevalence downwards, possibly through disease

422 associated mortality as shown in the force of infection model. Evidence of such confounding

423 effects was supported by our finding that swimbladder damage was positively correlated with eel

424 length, but weakly correlated with parasite abundance.

River system was also found to be a potential source of variation in parasite abundance,

426 but not swimbladder damage. In particular, the Potomac River had overall lower parasite 
427 abundance compared to the other river systems. These variations in infection, transmission, and

428 disease by season, size, and site observed in our study could be explained by a variety of

429 environmental and ecological factors (Hein et al. 2014; Moser et al. 2001; Fenske et al. 2010;

430 Hein et al. 2015; Morrison and Secor 2003; Machut and Limburg 2008; Aieta and Oliveira

431 2009). For example, higher salinity has been shown to have a negative effect on $\mathrm{A}$. crassus

432 infection (Kirk et al. 2000; Lefebvre and Crivelli 2012), but we could not investigate this

433 covariate because we did not measure salinity in this study. Additionally, different locations and

434 seasons could have different availabilities of $A$. crassus or intermediate hosts and could vary

435 with other factors such as temperature, which could impact $A$. crassus transmission and infection

436 levels in eels (De Charleroy et al. 1989; Kennedy and Fitch 1990; Molnar et al. 1991; Molnar

437 1993). These and other environmental parameters warrant further investigation.

Parasite abundance and swimbladder damage are two metrics useful in characterizing $A$.

439 crassus infection, although we found that they are weakly correlated; a higher parasite

440 abundance may not directly correlate to more swimbladder damage. Although the estimated

441 mean parasite abundance was highest for the highest SDI score of 6 and lowest for the lowest

442 SDI score of 0 , intermediate values of the metrics did not increase directly linearly. Additionally,

443 at higher parasite abundances, the probabilities of having a severely damaged swimbladder

444 versus a mildly damaged swimbladder were almost indistinguishable. Yet moderate damage had

445 an overall higher probability across the range of parasite abundances. A nonlinear relationship

446 was also found by several studies on European eels (Lefebvre et al. 2002; Lefebvre et al. 2013),

447 but is not well documented for American eels.

The nonlinear relationship between parasite count and swimbladder damage may be

449 caused by various aspects of the complex relationship between $A$. crassus and American eels. 
450 Nematodes can die within the swimbladder and degrade or be cleared out, but leave behind

451 damaged tissue. Also, there may be a lag between nematode presence and damage accumulation

452 such that multiple infections may occur before damage accrues (Van Banning and Haenen 1990;

453 Molnar et al 1993; Wurtz and Tarachewski 2000). Additionally, density dependence among $A$.

454 crassus exists such that more adult nematodes within the lumen can arrest further movement of

455 larval nematodes into the lumen (Ashworth and Kennedy 1999). Furthermore, as a swimbladder

456 becomes more damaged, it becomes a less suitable habitat for nematodes (Van Banning and

457 Haenen 1990; Molnar et al. 1993). Therefore, a swimbladder can be in poor condition but it may

458 have no nematodes within it or it can appear healthy and harbor many parasites. Lefevbre et al.

$459(2002,2013)$ suggested that the health state of the swimbladder may be a better long-term

460 indicator of overall infection history than number of living nematodes present at a given time.

461 Nematode count represents parasite pressure at a single point in time, whereas swimbladder

462 damage shows past and present damage, thereby potentially giving a more comprehensive

463 indication of infection severity.

464 The complexities in the dynamics of disease also likely play a role in the transmission, or

465 force of infection, of the parasite. The peak of FOI at age- 2 indicated that most eels first become

466 infected shortly after entering the estuary. However, it is important to note that in this study FOI

467 was modeled using swimbladder damage rather than prevalence of the nematode, and how long

468 it takes infection to result in detectable disease is unknown. If, as our previous analyses indicate,

469 there is a lag between infection and swimbladder damage, our FOI results could also suggest that

470 eels acquire the majority of nematodes in the spring, which then results in peak visible

471 swimbladder damage in the summer months. This is consistent with our findings that parasite

472 abundance is highest in the spring and severe swimbladder damage is highest in the summer. 
473 Eels likely do not accumulate more damage in the spring because they are not becoming re-

474 infected in the winter due to dormancy and lack of feeding (Kennedy and Fitch 1990) as

475 indicated by the lower FOI in March/April.

476 Importantly, the FOI model indicated that there is lower annual survival of eels with

477 moderate to severe swimbladder damage compared to those with very low or no damage. This

478 finding is supported by the overall low probability of eels having a severely damaged

479 swimbladder; if severe damage increases the likelihood of mortality, then there would a lower

480 chance of catching eels with such badly damaged swimbladders. Previous studies have shown

481 that higher $A$. crassus infection prevalence and intensity affect the ability of eels to swim,

482 tolerate hypoxic conditions or high temperatures, avoid hydraulic dams, and avoid predators and

483 fishing pressure (Molnar et al. 1991; Molnar 1993; Gollock et al. 2005; Lefebvre and Crivelli

484 2007), creating potential sources of elevated mortality. Because the FOI model is not able to

485 differentiate between mortality and recovery, more research is needed to determine if recovery

486 could also be occurring. The ability of the swimbladder to recover from infection is speculated

487 but not definitely shown to occur (Molnàr et al. 1994; Szèkely et al. 2005; Lefebvre et al. 2012).

488 It is possible that due to the widespread availability of $A$. crassus intermediate and paratenic

489 hosts and the lack of acquired immunity (Knopf 2006), eels may be constantly exposed to the

490 nematode and never have the opportunity or ability to fully recover, although partial healing of

491 the swimbladder could be possible. Clearance of individual nematodes from the swimbladder

492 through either decay or forced exit through the pneumatic duct would result in fewer nematodes

493 within the swimbladder and would represent recovery by the definition of the FOI model if

494 disease prevalence is defined as nematode prevalence. Yet, the relationship between parasite load

495 and swimbladder damage is complex and fewer parasites does not necessarily mean a less 
damaged organ. For these reasons, $A$. crassus infection prevalence was determined to not be a suitable parameter for the FOI model.

In conclusion, parasite load and swimbladder damage, although related, illustrate different components of this complex host parasite relationship. Parasite abundance shows parasite pressure at a given point in time, whereas swimbladder damage is integrative and likely represents the accumulation of disease and its negative impacts over time. Additionally, we have shown that $A$. crassus infection may contribute to American eel mortality and therefore may require consideration in future American eel stock assessments. A better understanding of the timeline of the lifecycle of $A$. crassus would make it possible to determine if fluctuations in parasite abundance and swimbladder damage are due to parasite availability or mortality. These fluctuations could also be better informed with information regarding the lag between nematode infection and swimbladder damage, in addition to the ability for eels to recover from infection.

\section{ACKNOWLEDGEMENTS}

This work was funded by the Virginia Sea Grant Graduate Research Fellowship and a Virginia Institute of Marine Science Foundation Fellowship. The research would not have been possible without the generous help from the VIMS young-of-year American Eel survey, which collected glass eels and elvers and was funded by the Virginia Marine Resources Commission (VMRC; through the Recreational Fishing Advisory Board and the Commercial Fishing Advisory Board), as well as the Potomac River Fisheries Commission. Additionally, the VIMS Juvenile Fish Trawl Survey and Striped Bass Seine Survey (funded by VMRC and Federal Aid to Sport Fish Restoration and the Commonwealth of Virginia) collected yellow eels for this study. The map in Figure 1 was created by Debra Gauthier of the Multispecies Research Group at VIMS. We would like to thank two anonymous reviewers for valuable feedback. We also appreciate the generous cooperation of the Virginia Department of Game and Inland Fisheries, in particular Aaron Bunch, who organized the collection of yellow eels from various electrofishing 
522 surveys around the state and allowed us to use their data for this research. This paper is

523 Contribution No. 3791 of the Virginia Institute of Marine Science, College of William \& Mary.

524

525

526

527

528

529

530

531

532

533

534

535

536

537

538

539

540

541

542

543

544

545

546

547

548

549

550

551

552

553

554

555

556

557

558

559

560

561

562

563

564

565

566 


\section{REFERENCES}

Agresti, A. 2010. Analysis of ordinal categorical data. John Wiley \& Sons, Hoboken, NJ.

Aieta, A.E., and Oliveira, K. 2009. Distribution, prevalence, and intensity of the swimbladder parasite Anguillicola crassus in New England and eastern Canada. Dis. Aquat. Organ. 84: 229-35. doi:10.3354/dao02049.

Ashworth, S.T., and Kennedy, C.R. 1999. Density-dependent effects on Anguillicola crassus (Nematoda) within its European eel definitive host. Parasitology 118(3): 289-296.

Atlantic States Marine Fisheries Commission. 2012. American Eel Benchmark Stock Assessment for Peer Review. Stock Assessment Report No. 12-01.

Barse, A.M., Mcguire, S.A., Vinores, M.A., Eierman, L.E., and Weeder, J.A. 2001. The swimbladder nematode Anguillicola crassus in American eels (Anguilla rostrata) from middle and upper regions of Chesapeake Bay. J. Parasitol. 87(6): 1366-1370. doi:10.1645/0022-3395(2001)087[1366:TSNACI]2.0.CO;2.

Barse, A.M., and Secor, D.H. 1999. An exotic nematode parasite of the American eel. Fisheries 24(2): 6-10. doi:10.1577/1548-8446(1999)024.

Bush, A.O., Lafferty, K.D., Lotz, J.M., and Shostak, A.W. 1997. Parasitology meets ecology on its own terms: Margolis et al. revisited. J. Parasitol. 83(4): 575-583. doi: $10.2307 / 3284227$.

Burnham, K.P., and Anderson, D.R. 2002. Model selection and inference: a practical information-theoretic approach, Springer, New York, NY.

Castonguay, M., Hodson, P.V., Couillard, C.M., Eckersley, M.J., Dutil, J.-D., and Verreault, G. 1994. Why is recruitment of the American eel, Anguilla rostrata, declining in the St. Lawrence River and Gulf? Can. J. Fish. Aquat. Sci. 51(2): 479-488. doi:10.1139/f94050.

Christensen, R.H.B. 2015. A tutorial on fitting cumulative link models with the ordinal package [online]. Available from https://cran.rproject.org/web/packages/ordinal/vignettes/clm tutorial.pdf [accessed 14 August 2017].

Cieri, M.D., and McCleave, J.D. 2000. Discrepancies between otoliths of larvae and juveniles of the American eel: is something fishy happening at metamorphosis? J. Fish Biol. 57: 1189-1198. doi:10.1006/jfbi.2000.1381.

De Charleroy, D., Grisez, L., Thomas, K., Belpaire, C., and Ollevier, F. 1990. The life cycle of Anguillicola crassus. Dis. Aquat. Organ. 8: 77-84. doi:10.3354/dao008077. 
De Charleroy, D., Thomas, K., Belpaire, C., and Ollevier, F. 1989. The viability of the free living larvae of Anguillicola crassus. J. Appl. Ichthyol. 5: 154-156. doi:10.1111/j.14390426.1989.tb00487.x.

Fenske, K.H., Secor, D.H., and Wilberg, M.J. 2010. Demographics and parasitism of American eels in the Chesapeake Bay, USA. Trans. Am. Fish. Soc. 139(6): 1699-1710. doi:10.1577/T09-206.1.

Fries, L.T., Williams, D.J., and Johnson, S.K. 1996. Notes: Occurrence of Anguillicola crassus, an exotic parasitic swim bladder nematode of eels, in the southeastern United States. Trans. Am. Fish. Soc. 125(5): 794-797. doi:10.1577/15488659(1996)125<0794:NOOCAE $>2.3 . \mathrm{CO} ; 2$.

Gollock, M.J., Kennedy, C.R., and Brown, J.A. 2005. European eels, Anguilla anguilla (L.), infected with Anguillicola crassus exhibit a more pronounced stress response to severe hypoxia than uninfected eels. J. Fish Dis. 28: 429-436. doi:10.1111/j.13652761.2005.00649.x.

Haenen, O.L.M., Grisez, L., De Charleroy, D., Belpaire, C., and Ollevier, F. 1989. Experimentally induced infections of European eel Anguilla anguilla with Anguillicola crassus (Nematoda, Dracunculoidea) and subsequent migration of larvae. Dis. Aquat. Organ. 7: 97-101. doi:10.3354/dao007097.

Haro, A., Richkus, W., Whalen, K., Hoar, A., Busch, W.-D., Lary, S., Brush, T., and Dixon, D. 2000. Population decline of the American eel: implications for research and management. Fisheries 25(9): 7-16. Taylor \& Francis Group. doi:10.1577/15488446(2000)025<0007:PDOTAE>2.0.CO;2.

Haro, A.J., and Krueger, W.H. 1988. Pigmentation, size, and migration of elvers (Anguilla rostrata (Lesueur)) in a coastal Rhode Island stream. Can. J. Zool. 66: 2528-2533. doi:10.1139/z88-375.

Hedeker, D. 2003. A mixed-effects multinomial logistic regression model. Stat. Med. 22: 14331446. https://doi.org/10.1002/sim.1522

Hein, J.L., Arnott, S.A., Roumillat, W.A., Allen, D.M., and de Buron, I. 2014. Invasive swimbladder parasite Anguillicoloides crassus: infection status 15 years after discovery in wild populations of American eel Anguilla rostrata. Dis. Aquat. Organ. 107: 199-209. doi:10.3354/dao02686.

Hein, J.L., Buron, I. De, Roumillat, W.A., Post, W.C., Hazel, A.P., and Arnott, S.A. 2015. Infection of newly recruited American eels (Anguilla rostrata) by the invasive swimbladder parasite Anguillicoloides crassus in a US Atlantic tidal creek. ICES J. Mar. Sci.: 1-8. doi:10.1093/icesjms/fsv097. 
671

672

673

674

675

676

677

678

679

680

681

682

683

684

685

686

687

688

689

690

691

692

693

694

695

696

697

698

699

700

701
Heisey, D.M., Joly, D.O., and Messier, F. 2006. The fitting of general force-of-infection models to wildlife disease prevalence data. Ecology 87(9): 2356-2365. doi:10.1890/00129658(2006)87[2356:TFOGFM]2.0.CO;2.

Kennedy, C.R., and Fitch, D.J. 1990. Colonization, larval survival and epidemiology of the nematode Anguillicola crassus, parasitic in the eel, Anguilla anguilla, in Britain. J. Fish Biol. 36: 117-131. doi:10.1111/j.1095-8649.1990.tb05588.x.

Kim, Y.-G., Kim, E.-B., Kim, J.-Y., and Chun, S.-K. 1989. Studies on a nematode, Anguillicola crassus parasitic in the air bladder of the eel. J. fish Pathol. 2(1): 1-18.

Kirk, R.S., Kennedy, C.R., and Lewis, J.W. 2000. Effect of salinity on hatching, survival and infectivity of Anguillicola crassus (Nematoda: Dracunculoidea) larvae. Dis. Aquat. Organ. 40: 211-218. doi:10.3354/dao040211.

Knopf, K. 2006. The swimbladder nematode Anguillicola crassus in the European eel Anguilla anguilla and the Japanese eel Anguilla japonica: differences in susceptibility and immunity between a recently colonized host and the original host. J. Helminthol. 80: 129-136. doi:10.1079/JOH2006353.

Knopf, K., Naser, K., van der Heijden, M.H., and Taraschewski, H. 2000. Humoral immune response of European eel Anguilla anguilla experimentally infected with Anguillicola crassus. Dis. Aquat. Organ. 42(1): 61-9. doi:10.3354/dao042061.

Knopf, K., Würtz, J., Sures, B., and Taraschewski, H. 1998. Impact of low water temperature on the development of Anguillicola crassus in the final host Anguilla anguilla. Dis. Aquat. Organ. 33: 143-149. doi:10.3354/dao033143.

Kobayashi, H., Pelster, B., and Scheid, P. 1990. CO2 back-diffusion in the rete aids O2 secretion in the swimbladder of the eel. Respir. Physiol. 79(3): 231-242. doi:10.1016/00345687(90)90129-M.

Lefebvre, F., Contournet, P., and Crivelli, A.J. 2002. The health state of the eel swimbladder as a measure of parasite pressure by Anguillicola crassus. Parasitology 124: 457-463. doi:10.1017/S0031182001001378.

Lefebvre, F., Contournet, P., and Crivelli, A.J. 2007. Interaction between the severity of the infection by the nematode Anguillicola crassus and the tolerance to hypoxia in the European eel Anguilla anguilla. Acta Parasitol. 52(2): 171-175. doi:10.2478/s11686-0070013-4.

Lefebvre, F., and Crivelli, A.J. 2012. Salinity effects on Anguillicolosis in Atlantic eels: A natural tool for disease control. Mar. Ecol. Prog. Ser. 471: 193-202. doi:10.3354/meps10032. 
Lefebvre, F., Fazio, G., Mounaix, B., and Crivelli, A.J. 2013. Is the continental life of the European eel Anguilla anguilla affected by the parasitic invader Anguillicoloides crassus? Proc. R. Soc. B 280: 20122916. doi:10.1098/rspb.2012.2916.

Lefebvre, F., Fazio, G., Palstra, A.P., Székely, C., and Crivelli, A.J. 2011. An evaluation of indices of gross pathology associated with the nematode Anguillicoloides crassus in eels. J. Fish Dis. 34: 31-45. doi:10.1111/j.1365-2761.2010.01207.x.

Machut, L.S., and Limburg, K.E. 2008. Anguillicola crassus infection in Anguilla rostrata from small tributaries of the Hudson River watershed, New York, USA. Dis. Aquat. Organ. 79: 37-45. doi:10.3354/dao01901.

McCullagh, P. 1980. Regression Models for Ordinal Data. J. R. Stat. Soc. B. 42: 109-142.

Michaud, M., Dutil, J.-D., and Dodson, J.J. 1988. Determination of the age of young American eels, in fresh water, based on otolith surface area and microstructure. J. Fish Biol. 32: 179-189. doi:10.1111/j.1095-8649.1988.tb05351.x.

Molnár, K. 1993. Effects of decreased oxygen content on eels (Anguilla anguilla) infected by Anguillicola crassus (Nematoda: Dracunculoidae). Acta Vet. Hunganca 43(3-4): 349360.

Molnár, K., Baska, F., Csaba, G., Glavits, R., and Szekely, C. 1993. Pathological and histopathological studies of the swimbladder of eels Anguilla anguilla infected by Anguillicola crassus (Nematoda: Dracunculoidea). Dis. Aquat. Organ. 15: 41-50. doi:10.3354/dao015041.

Molnár, K., Szakolczai, J., and Vetési, F. 1995. Histological changes in the swimbladder wall of eels due to abnormal location of adult and second stage larvae of Anguillicola crassus. Acta Vet. Hung. 43(1): 125-137.

Molnár, K., Székely, C., and Baska, F. 1991. Mass mortality of eel in Lake Balaton due to Anguillicola crassus infection. Bull. Eur. Assoc. Fish Pathol. 11(6): 211-212.

Molnár, K., Székely, C., and Perényi, M. 1994. Dynamics of Anguillicola crassus (Nematoda: Dracunculoidea) infection in eels of Lake Balaton, Hungary. Folia Parasitol. (Praha). 41: 193-202. doi:10.1017/CBO9781107415324.004.

Moravec, F. 1996. Aquatic invertebrates (snails) as new paratenic hosts of Anguillicola crassus (Nematoda: Dracunculoidea) and the role of paratenic hosts in the life cycle of this parasite. Dis. Aquat. Org. 27: 237-239. doi:10.3354/dao027237.

Moravec, F., and Skoríková, B. 1998. Amphibians and larvae of aquatic insects as new paratenic hosts of Anguillicola crassus (Nematoda: Dracunculoidea), a swimbladder parasite of eels. 34(1996): 217-222. doi:10.3354/dao034217. 
Morrison, W.E., and Secor, D.H. 2003. Demographic attributes of yellow-phase American eels (Anguilla rostrata) in the Hudson River estuary. Can. J. Fish. Aquat. Sci. 60: 1487-1501. doi:10.1139/f03-129.

Moser, M.L., Patrick, W.S., and Jr., J.U.C. 2001. Infection of American eels, Anguilla rostrata, by an introduced nematode parasite, Anguillicola crassus, in North Carolina. Available from http://www.asihcopeiaonline.org/doi/abs/10.1643/00458511(2001)001\%5B0848:IOAEAR\%5D2.0.CO\%3B2 [accessed 22 September 2014].

Nagasawa, K., Kim, Y.-G., and Hirose, H. 1994. Anguillicola crassus and A. globiceps (Nematoda: Dracunculoidea) parasitic in the swimbladder of eels (Anguilla japonica and A. anguilla) in East Asia: A review. Folia Parasitol. (Praha). 41: 127-137.

Ooi, H.K., Wang, W.S., Chang, H.Y., Wu, C.H., Lin, C.C., and Hsieh, M.T. 1996. An epizootic of Anguillicolosis in cultured American eels in Taiwan. J. Aquat. Anim. Health 8(2): 163-166. doi:10.1577/1548-8667(1996)008<0163:AEOAIC >2.3.CO;2.

R Core Team. 2017. R: A language and environment for statistical computing. R Foundation for Statistical Computing, Vienna, Austria. URL https://www.R-project.org/.

Rockwell, L.S., Jones, K.M.M., and Cone, D.K. 2009. First Record of Anguillicoloides crassus (Nematoda) in American Eels (Anguilla rostrata) in Canadian Estuaries, Cape Breton, Nova Scotia. J. Parasitol. 95(2): 483-486. doi:10.1645/GE-1739.1.

Seber. 1982. The Estimation of Animal Abundance, $2^{\text {nd }}$ ed. Griffin, London.

Searle, S.R., Speed, F.M., and Milliken, G.A. 1980. Population marginal means in the linear model: an alternative to least squares means. Am. Stat. 34(4): 216-221. doi:10.1080/00031305.1980.10483031.

Sokolowski, M.S., and Dove, A.D.M. 2006. Histopathological examination of wild American eels infected with Anguillicola crassus. J. Aquat. Anim. Health 18(4): 257-262. doi:10.1577/H06-009.1.

Székely, C., Molnár, K., and Rácz, O.Z. 2005. Radiodiagnostic method for studying the dynamics of Anguillicola crassus (Nematoda: Dracunculoidea) infection and pathological status of the swimbladder in Lake Balaton eels. Dis. Aquat. Organ. 64: 53-61. doi:10.3354/dao064053.

Thomas, K., and Ollevier, F. 1992. Population biology of Anguillicola crassus in the final host Anguilla anguilla. Dis. Aquat. Organ. 14: 163-170.

Tuckey, T.D., and Fabrizio, M.C. 2013. Influence of survey design on fish assemblages: implications from a study in Chesapeake Bay Tributaries. Trans. Am. Fish. Soc. 142(4): 957-973. doi:10.1080/00028487.2013.788555. 
Van Banning, P. and Haenen, O.L.M. 1990. Effects of the swimbladder nematode Anguillicola crassus in wild and farmed eel, Anguilla anguilla. In Pathology in marine science. Edited by F.O. Perkins and T.C. Cheng. Academic Press, New York, NY. pp. 317-330.

Wang, C.H., and Tzeng, W.N. 1998. Interpretation of geographic variation in size of American eel Anguilla rostrata elvers on the Atlantic coast of North America using their life history and otolith ageing. Mar. Ecol. Prog. Ser. 168: 35-43. doi:10.3354/meps168035.

Würtz, J., and Taraschewski, H. 2000. Histopathological changes in the swimbladder wall of the European eel Anguilla anguilla due to infections with Anguillicola crassus. Dis. Aquat. Organ. 39: 121-134. doi:10.3354/dao039121.

Würtz, J., Taraschewski, H., and Pelster, B. 1996. Changes in gas composition in the swimbladder of the European eel (Anguilla anguilla) infected with Anguillicola crassus (Nematoda). Parasitology 112: 233-238. doi:10.1017/S003118200008481X.

Zeileis, A., Kleiber, C., and Jackman S. 2008. Regression models for count data in R. Journal of Statistical Software. 27:8.

Zuur, A.F., Saveliev, A.A., and Ieno, E.N. 2012. Zero Inflated Models and Generalized Linear Mixed Models. Highland Statistics Limited.

(1)

(1)

.

2

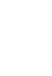

5

(5)

7

9

1


TABLES

841

842 Table 1. Prevalence (\%), mean abundance (SE; range), and mean intensity (SE) of

843 Anguillicoloides crassus, and swimbladder degenerative index (SDI; SE) in American eels by

844 river system and eel stage.

845

\begin{tabular}{|c|c|c|c|c|c|c|}
\hline Location & Stage & $\mathrm{N}$ & $\begin{array}{l}\text { Prevalence } \\
(\%)\end{array}$ & Abundance & Intensity & SDI \\
\hline \multirow[t]{4}{*}{ Potomac } & Glass & 116 & 5.2 & $\begin{array}{l}0.05 \\
(0.02 ; 0-1)\end{array}$ & $\begin{array}{l}1 \\
(0)\end{array}$ & $\begin{array}{l}0.02 \\
(0.01)\end{array}$ \\
\hline & Elver & 269 & 59.6 & $\begin{array}{l}1.26 \\
(0.09 ; 0-10)\end{array}$ & $\begin{array}{l}2.11 \\
(0.11)\end{array}$ & $\begin{array}{l}1.81 \\
(0.1)\end{array}$ \\
\hline & Yellow & 29 & 55.2 & $\begin{array}{l}1.21 \\
(0.24 ; 0-4)\end{array}$ & $\begin{array}{l}2.19 \\
(0.23)\end{array}$ & $\begin{array}{l}1.97 \\
(0.38)\end{array}$ \\
\hline & Total & 414 & 44 & $\begin{array}{l}0.91 \\
(0.07 ; 0-10)\end{array}$ & $\begin{array}{l}2.08 \\
(0.1)\end{array}$ & $\begin{array}{l}1.28 \\
(0.08)\end{array}$ \\
\hline \multirow[t]{4}{*}{ Rappahannock } & Glass & 249 & 2.4 & $\begin{array}{l}0.02 \\
(0.01 ; 0-1)\end{array}$ & $\begin{array}{l}1 \\
(0)\end{array}$ & $\begin{array}{l}0.01 \\
(0.01)\end{array}$ \\
\hline & Elver & 114 & 53.3 & $\begin{array}{l}1.13 \\
(0.15 ; 0-9)\end{array}$ & $\begin{array}{l}2.13 \\
(0.2)\end{array}$ & $\begin{array}{l}1.1 \\
(0.17)\end{array}$ \\
\hline & Yellow & 379 & 49.7 & $\begin{array}{l}1.53 \\
(0.13 ; 0-21)\end{array}$ & $\begin{array}{l}3.09 \\
(0.22)\end{array}$ & $\begin{array}{l}1.03 \\
(0.15)\end{array}$ \\
\hline & Total & 742 & 34.2 & $\begin{array}{l}0.96 \\
(0.08 ; 0-21)\end{array}$ & $\begin{array}{l}2.82 \\
(0.17)\end{array}$ & $\begin{array}{l}1.43 \\
(0.06)\end{array}$ \\
\hline \multirow[t]{4}{*}{ York } & Glass & 744 & 0 & $\begin{array}{l}0 \\
(0)\end{array}$ & $\begin{array}{l}0 \\
(0)\end{array}$ & $\begin{array}{l}0.002 \\
(0.002)\end{array}$ \\
\hline & Elver & 230 & 64.8 & $\begin{array}{l}1.72 \\
(0.13 ; 0-10)\end{array}$ & $\begin{array}{l}2.66 \\
(0.15)\end{array}$ & $\begin{array}{l}1.52 \\
(0.1)\end{array}$ \\
\hline & Yellow & 153 & 45.1 & $\begin{array}{l}1.23 \\
(0.23 ; 0-28)\end{array}$ & $\begin{array}{l}2.77 \\
(0.45)\end{array}$ & $\begin{array}{l}2.85 \\
(0.15)\end{array}$ \\
\hline & Total & 1127 & 18.6 & $\begin{array}{l}0.5 \\
(0.05 ; 0-28)\end{array}$ & $\begin{array}{l}2.7 \\
(0.18)\end{array}$ & $\begin{array}{l}0.67 \\
(0.04)\end{array}$ \\
\hline \multirow[t]{4}{*}{ James } & Glass & 371 & 0 & $\begin{array}{l}0 \\
(0)\end{array}$ & $\begin{array}{l}0 \\
(0)\end{array}$ & $\begin{array}{l}0.01 \\
(0.003)\end{array}$ \\
\hline & Elver & 201 & 66.7 & $\begin{array}{l}1.83 \\
(0.13 ; 0-7)\end{array}$ & $\begin{array}{l}2.73 \\
(0.13)\end{array}$ & $\begin{array}{l}1.82 \\
(0.11)\end{array}$ \\
\hline & Yellow & 412 & 43 & $\begin{array}{l}1.24 \\
(0.11 ; 0-18)\end{array}$ & $\begin{array}{l}2.88 \\
(0.19)\end{array}$ & $\begin{array}{l}2.3 \\
(0.08)\end{array}$ \\
\hline & Total & 984 & 50.6 & $\begin{array}{l}1.43 \\
(0.08 ; 0-18)\end{array}$ & $\begin{array}{l}2.82 \\
(0.12)\end{array}$ & $\begin{array}{l}1.32 \\
(0.05)\end{array}$ \\
\hline
\end{tabular}


847 Table 2. Model components and estimates from the most empirically supported model describing 848 the effects of covariates on count of Anguillicoloides crassus in American eels.

849

\begin{tabular}{|c|c|c|c|c|}
\hline $\begin{array}{l}\text { Model } \\
\text { Component }\end{array}$ & Parameter & Level & Estimate & Standard Error \\
\hline \multirow[t]{18}{*}{ Zero-inflated } & River system & James & Baseline & $\mathrm{N} / \mathrm{A}$ \\
\hline & & Potomac & -16.8 & 0.002 \\
\hline & & Rappahannock & -0.423 & 0.295 \\
\hline & & York & -0.357 & 0.288 \\
\hline & Season & & & \\
\hline & & Fall & Baseline & N/A \\
\hline & & Winter & -12.5 & 225 \\
\hline & & Spring & 0.724 & 0.358 \\
\hline & & Summer & 0.746 & 0.375 \\
\hline & $\begin{array}{c}\text { Total length } \\
\text { SDI }\end{array}$ & & 0.0064 & 0.001 \\
\hline & & 0 & Baseline & N/A \\
\hline & & 1 & -1.36 & 0.470 \\
\hline & & 2 & -0.656 & 0.620 \\
\hline & & 3 & -0.758 & 0.359 \\
\hline & & 4 & -1.19 & 0.503 \\
\hline & & 5 & -0.402 & 0.464 \\
\hline & & 6 & -1.48 & 1.11 \\
\hline & River system & & & \\
\hline \multirow{17}{*}{$\begin{array}{c}\text { Count (negative } \\
\text { binomial) }\end{array}$} & & James & Baseline & N/A \\
\hline & & Potomac & -0.452 & 0.112 \\
\hline & & Rappahannock & -0.135 & 0.103 \\
\hline & & York & -0.015 & 0.103 \\
\hline & Season & & & \\
\hline & & Fall & Baseline & N/A \\
\hline & & Winter & -0.149 & 0.316 \\
\hline & & Spring & 0.294 & 0.130 \\
\hline & & Summer & 0.224 & 0.138 \\
\hline & Total length & & 0.0014 & $4 \times 10^{-4}$ \\
\hline & SDI & 0 & Baseline & N/A \\
\hline & & 1 & 0.279 & 0.124 \\
\hline & & 2 & 0.512 & 0.116 \\
\hline & & 3 & 0.295 & 0.131 \\
\hline & & 4 & 0.502 & 0.156 \\
\hline & & 5 & 0.387 & 0.194 \\
\hline & & 6 & 0.500 & 0.238 \\
\hline
\end{tabular}


858
Table 3. Model components and estimates from the most empirically supported model describing the effects of covariates on swimbladder damage $($ low $=0$, moderate $=1$, severe $=2$ ) from Anguillicoloides crassus in American eels. The "|" symbol in SDI Threshold indicates the threshold between swimbladder damage levels of the swimbladder degenerative index (SDI) for which the estimate of partial proportional odds applies for a given parameter. For example, $0 \mid 1$ indicates the probability an eel has an SDI of 0 versus all higher scores. Random effect estimate is the variance \pm standard deviation.

\begin{tabular}{lllll}
\hline Parameter type & Parameter & $\begin{array}{l}\text { SDI } \\
\text { Threshold }\end{array}$ & Estimate & $\begin{array}{l}\text { Standard } \\
\text { Error }\end{array}$ \\
\hline Intercepts & & $0 \mid 1$ & 0.387 & 0.288 \\
& & 3.15 & 0.310 \\
Proportional odds & Total Length & & 0.0042 & 0.001 \\
Partial proportional odds & Season & $0 \mid 1$ fall & Baseline & N/A \\
& & $1 \mid 2$ fall & Baseline & N/A \\
& & $0 \mid 1$ winter & -0.425 & 0.911 \\
& & $1 \mid 2$ winter & 0.641 & 0.971 \\
& & $0 \mid 1$ spring & 0.204 & 0.251 \\
& & $1 \mid 2$ spring & -0.049 & 0.267 \\
& & $0 \mid 1$ summer & 0.091 & 0.282 \\
& & $1 \mid 2$ summer & -0.800 & 0.294 \\
Random effect & & $0 \mid 1$ & -0.201 & 0.036 \\
& & $1 \mid 2$ & -0.117 & 0.036 \\
& Parasite count & & 1.423 & 1.197 \\
\hline
\end{tabular}


876

877

878

879

880

881

\begin{tabular}{lllllll}
\hline & \multicolumn{7}{c}{$\Delta$ AIC } \\
\cline { 2 - 7 } $\begin{array}{l}\text { Infection hazard } \\
\text { model }\end{array}$ & Null & $\mu$ & Season & $\begin{array}{l}\text { Season, } \\
\mu\end{array}$ & System & $\begin{array}{l}\text { System, } \\
\mu\end{array}$ \\
\hline constant & 40.6 & 7 & 35.1 & 11 & 40.3 & 6.5 \\
Weibull & 13.8 & 9 & 18.6 & 12.8 & 12 & 8.4 \\
Pareto & 9.2 & 7.5 & 13.9 & 11.8 & 8.5 & 7.9 \\
Gompertz & 5.3 & 7 & 10.4 & 11.6 & 5.5 & 7.5 \\
log-logistic & 11.2 & 3 & 15.7 & 6.4 & 10.4 & 5.5 \\
\hline
\end{tabular}

Table 4. Assessment of force-of-infection model fits for presence of swimbladder damage (SDI $\geq$ 2) in American eels based on Akaike's information criterion. Months were grouped in to pairs starting with January/February (i.e. month pairs). Catch sites were grouped by river system (Potomac, Rappahannock, York, James Rivers). $\mu$ is the disease associated mortality term.

\begin{tabular}{lllllll}
\hline & \multicolumn{7}{c}{$\Delta$ AIC } \\
\cline { 2 - 7 } $\begin{array}{l}\text { Infection hazard } \\
\text { model }\end{array}$ & $\begin{array}{l}\text { Season, } \\
\text { System }\end{array}$ & $\begin{array}{l}\text { Season, } \\
\text { System, } \mu\end{array}$ & $\begin{array}{l}\text { Month } \\
\text { pairs }\end{array}$ & $\begin{array}{l}\text { Month } \\
\text { pairs, } \mu\end{array}$ & $\begin{array}{l}\text { Month pairs, } \\
\text { System }\end{array}$ & $\begin{array}{l}\text { Month pairs, } \\
\text { System, } \mu\end{array}$ \\
\hline constant & 35.1 & 10.8 & 27.8 & 3.4 & 31.8 & 6.3 \\
Weibull & 17 & 12.5 & 10.2 & 5.3 & 11.9 & 8.2 \\
Pareto & 13.4 & 12.4 & 6.1 & 4.7 & 8.5 & 7.9 \\
Gompertz & 12.5 & 10.7 & 3.1 & 4.7 & 5.9 & 7.9 \\
log-logistic & 15.2 & 9.4 & 6.3 & 0 & 9.3 & 4.8 \\
\hline
\end{tabular}


FIGURES



Figure 1. Map of collection sites for glass and elver American eels from lower Chesapeake Bay, 903 USA. Potomac River: (1) Gardy's Millpond, (2) Clark’s Millpond; Rappahannock River: (3) 904 Kamp's Millpond; York River: (4) Bracken's Pond, (5) Wormley Pond; James River: (6) 905 Wareham's Pond. Map data from Arcinfo produced by Environmental Systems Research 906 Institute (ESRI, 1987). 


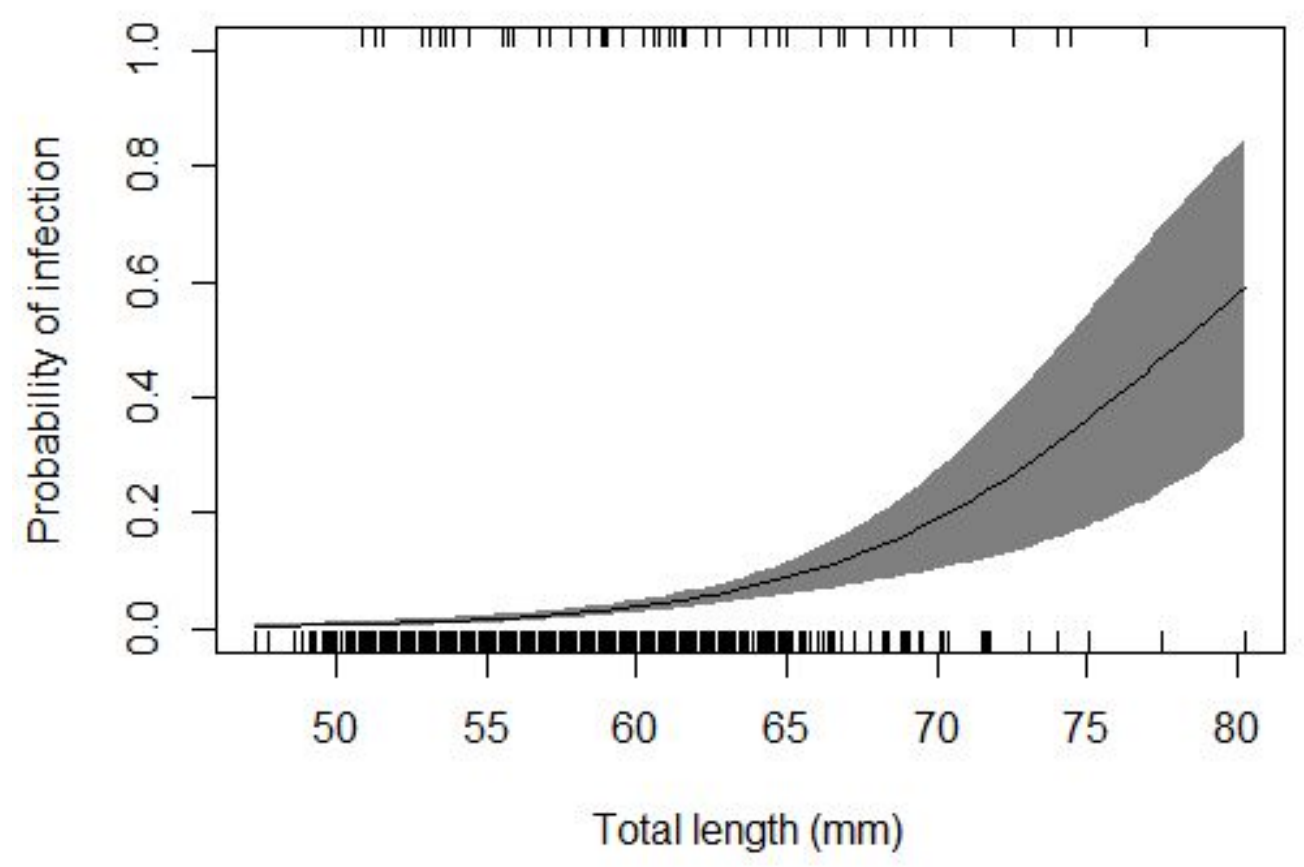

909

910

911

912

913

914

915

916

Figure 2. Probability of infection with larval and adult Anguillicoloides crassus by total length $(\mathrm{mm})$ for glass eels. Black line represents binomial model results with 95\% CI (grey shaded area). Tick marks are individual eel observations of infected (top of plot) or uninfected (bottom of plot). 
James
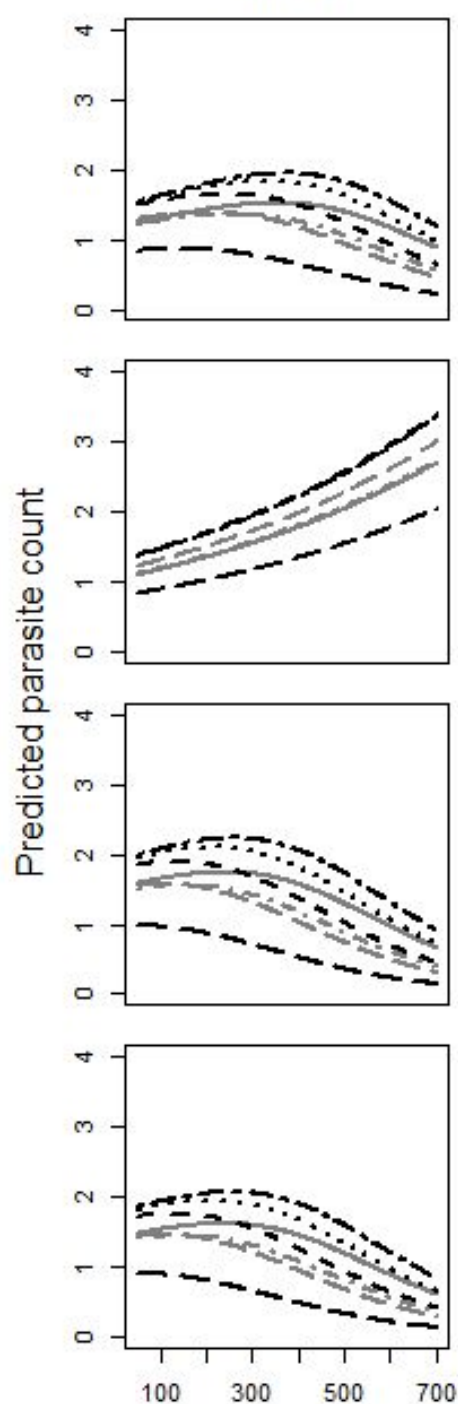

Potomac
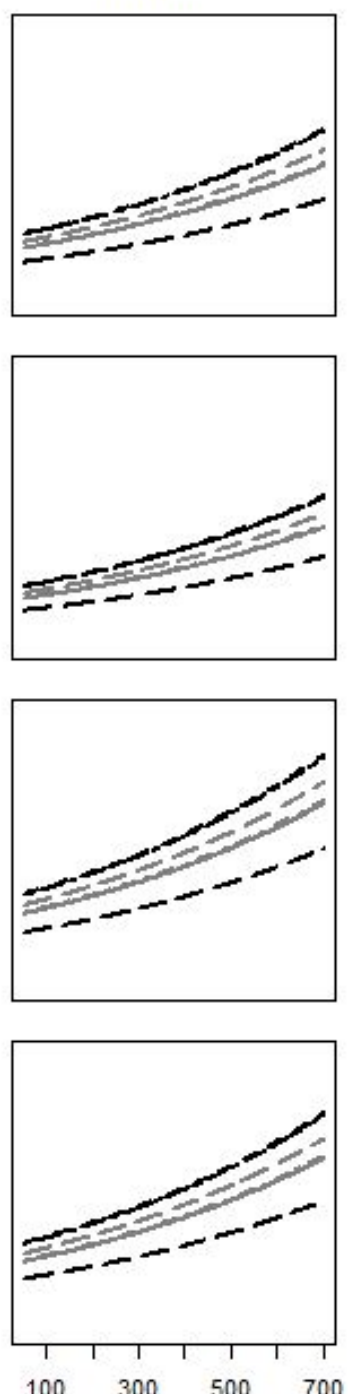

Rappahannock
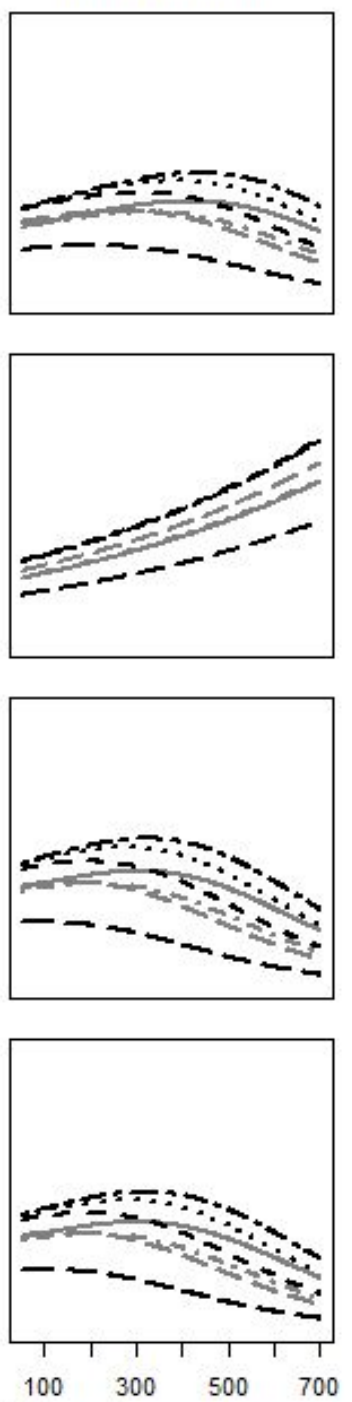

York
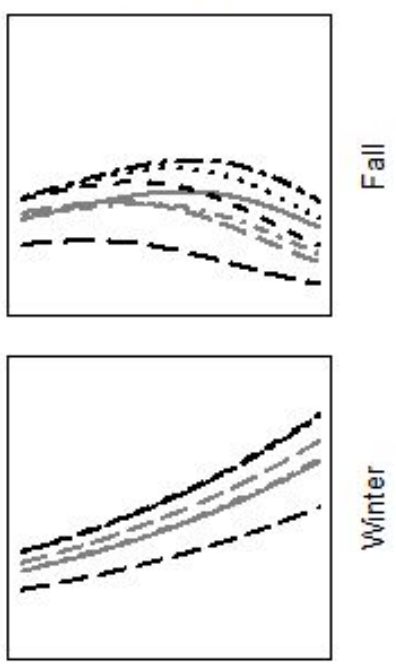

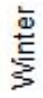


Total length $(\mathrm{mm})$

Figure 3. Predicted Anguillicoloides crassus parasite count for elver and yellow American eels for season of capture, system, total length ( $\mathrm{mm}$ ), and swimbladder degenerative index (SDI) total score. Results are from a zero-inflated negative binomial model. Individual lines represent SDI

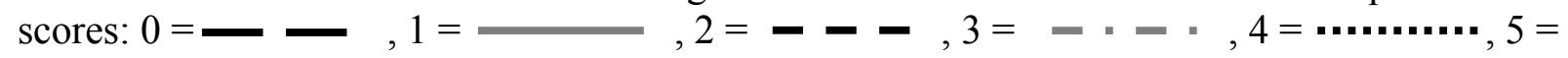

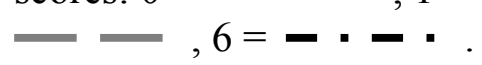



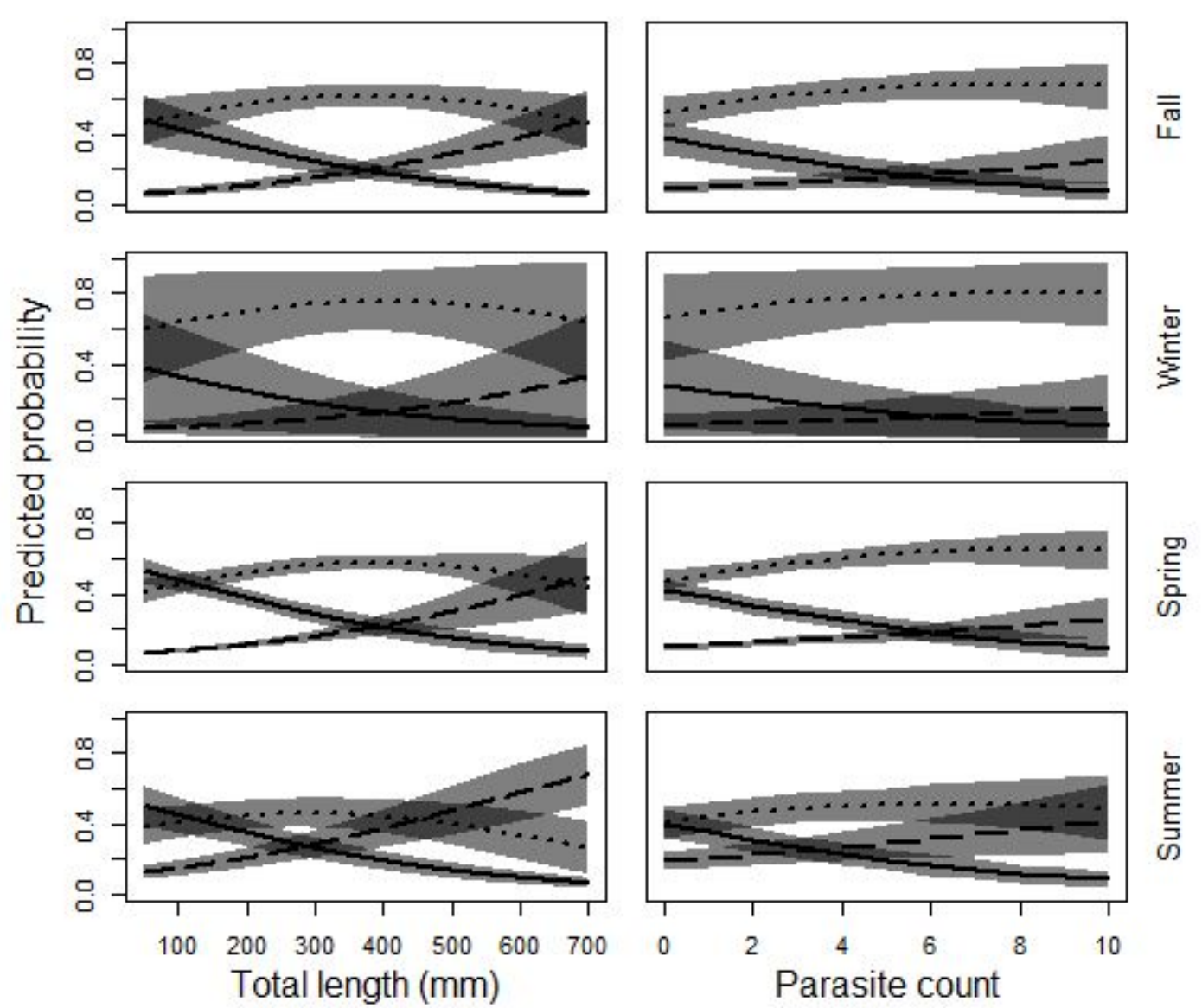

Figure 4. Predicted probability of elver and yellow eels being in a swimbladder condition category $($ low $=$ SDI $0-1$, — - - - ) by season of capture, total length (left panel), and $A$. crassus parasite count (right panel). Total length is held constant at its mean in right panel and parasite count is held constant at its mean in the left panel. Results are from the ordinal logistic regression with catch ID as a random effect. 




Figure 5. Prevalence of swimbladder damage ( $\mathrm{SDI} \geq 3$; open circles with solid line) and $A$. crassus (closed circle with dashed line) prevalence by age of elver and yellow American eels with confidence intervals. Numbers above $\mathrm{x}$-axis indicate sample size in each age group. Points are slightly offset for clarity. 


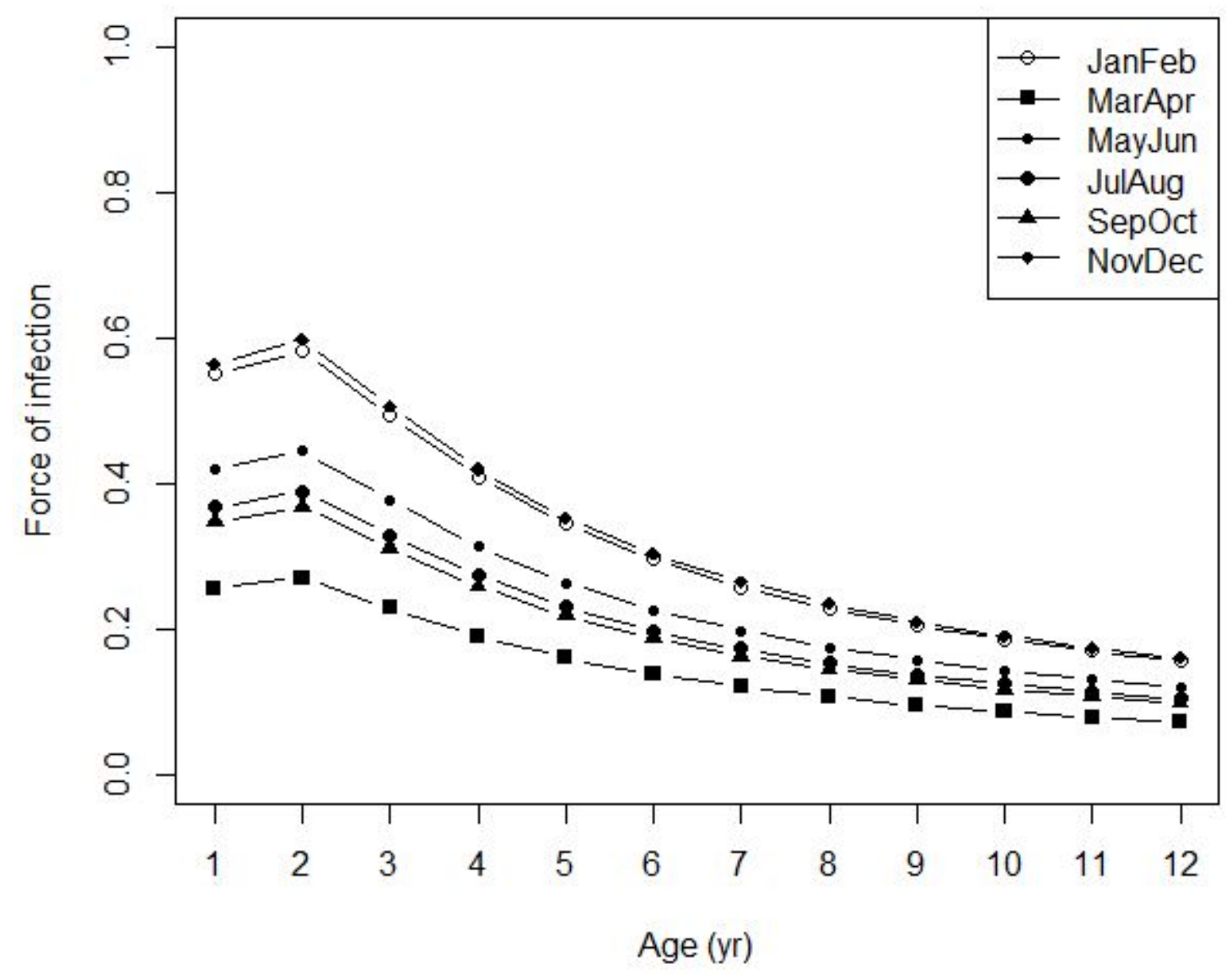

967

968

969

970

971

972

973

974

975

976

977

978

979

980

981

982

983

\section{0}

975

Figure 6. Force-of-infection of swimbladder damage by age for elver and yellow American eels by month pairs from best fitting force-of-infection model (log-logistic, month pair, mortality).

71

3

976

